\title{
Small anthropomorphic figurines in clay at Ģipka Neolithic settlements
}

\author{
Ilze Biruta Loze \\ Institute of History of Latvia, University of Latvia, Riga, Latvia \\ Ivi@lza.lv
}

\begin{abstract}
Miniature Neolithic figurines in clay are a special topic of research. This especially concerns areas where their representation has so far been poor. While carrying out archaeological excavations in Northern Kurzeme, the north west coastal dune zone of Riga Bay, a ritual-like complex was recovered at Gipka A site belonging to the local Culture of Pit Ceramics. It consists of several large and smaller fireplaces and pits, with the finds of fragmentary clay figurines recovered under the palisade that surrounded the settlement. The head and body of the miniature anthropomorphic figurines in clay have original modelling. It is possible to single out two types of figurine: with rather broad cheekbones, and oval modelling of face. The large amount of ochre found in the settlement and the purposeful breaking of figurines are evidence of their role during a rite. Clay figurines have a symbolic meaning, and the signs depicted on them, incised walking stick-shape and other motifs, are the symbols of early farmers.
\end{abstract}

IZVLEČEK - Predmet raziskave so neolitski miniaturni keramični kipci. Poudarek je na območjih, kjer so bili do sedaj redko zastopani. Pri arheoloških izkopavanjih v severni Kurzemi, na severozahodnem območju priobalnih sipin Riškega zaliva so na najdǐ̌ču Gipka A odkrili kompleks, ki sodi v lokalne neolitske kulture. Sestavlja ga več večjih in manjših ognjišč in jam. Pod palisado, ki obkroža naselje, pa so našli fragmentirane keramične kipce. Glava in telo miniaturnih antropomorfnih kipcev sta izvirno oblikovana. Ločimo lahko dva tipa kipcev: s precej širokimi ličnicami in z ovalno obliko obraza. Velika količina okre, ki so jo našli v naselbini, in namerno drobljenje kipcev dokazujeta njihovo vlogo pri obredjih. Keramični kipci imajo simbolni pomen. Znaki v obliki sprehajalne palice ter drugi motivi predstavljajo simbole zgodnjih poljedelcev.

KEY WORDS - figurines, red colour, ritual, symbols

\section{INTRODUCTION}

Anthropomorphic miniature plastic art in clay is a special topic in European Neolithic research. It is best represented in southeast Europe, where its rich representations are found at Neolithic dwellings. It has undergone classification, analysis, discussion and interpretation. The serial manufacture of anthropomorphic miniature ceramic plastic art was not characteristic of the northern hemisphere, nor was its accumulation in Neolithic dwellings. There are rather few samples in Yumala (Jomala) in the Alland group in Finland with the characteristic of Culture of Pit Cera- mics (Cederhvarf 1912.307-323). In the latter half of the 1930s, a dune settlement was discovered at Pūrciems, near the Gipka lagoon in Latvia, where Eduards Šturms succeeded in recovering the first miniature anthropomorhic figurines in clay (Šturms 1937a.46-54; 1937b.83-910) (Fig. 1). At the time the finds attracted much attention in neighbouring countries (Ayräpää 1942.82-123). Archaeological investigations carried out from 1993 to 2001 in Northern Kurzeme, in the narrow zone of the blownout dunes between the littoral of the Litorina Sea 
and the coast of the Gipka lagoon (later a lake) at Gipka A and B, opened up new possibilities for research in anthropomorphic miniature plastic art in clay of the Culture of Pit Ceramics (with porous structure) in the eastern part of the Baltic region (Fig. 2). Three papers discussing anthropomorphic figurines in clay from the Gipka A settlement have been published. We focused only on some aspects of ritual at the dune settlements in the Gipka dune area (Loze 2002.52- 61).

\section{CLASSIFICATION OF ANTHROPOMORPHIC FIGU- RINES}

The anthropomorphic figurines in clay found at sites Pürciems $C$ and $F$ and Gịkka $A$ and $B$ were classified by making use of fragmentary figurines - their broken off heads, breasts and other parts of the torso. An almost undamaged figurine from the Pūrciems C site served as a standard of comparison to determine the proportions of the figurines (Šturms 1937b.84, Fig. 1). The material under discussion includes one almost undamaged figurine and two fragmentary figurines from Pürciems C investigated in the 1930s, and 25 fragments from the archaeological excavations at sites Gipka A and B of the 1990s.

\section{Anthropomorphic Figurine with Head Turned Upward and a Flat Base in Place of Legs}

The samples of the above anthropomorphic Neolithic miniatures include one almost undamaged figurine found at the Pūrciems C site (Fig. 3). It has a large head the lower part being rather broad, a narrow

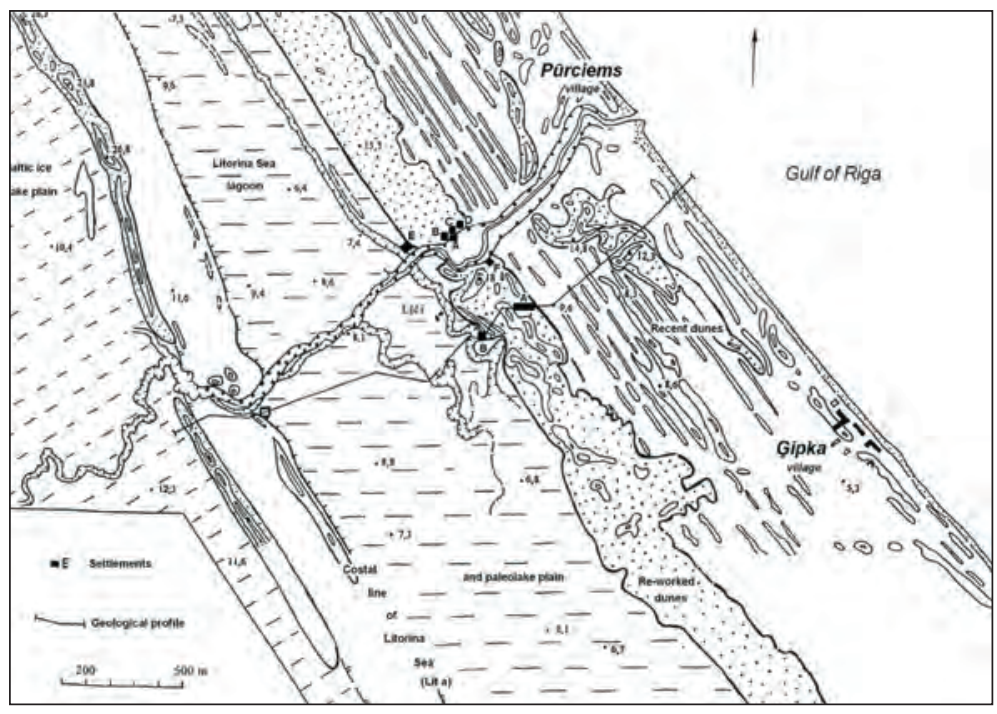

Fig. 2. Location of Gipka-Pürciems Neolithic settlements at the belt of re-worked dunes (after Loze, Eberhards 1998).

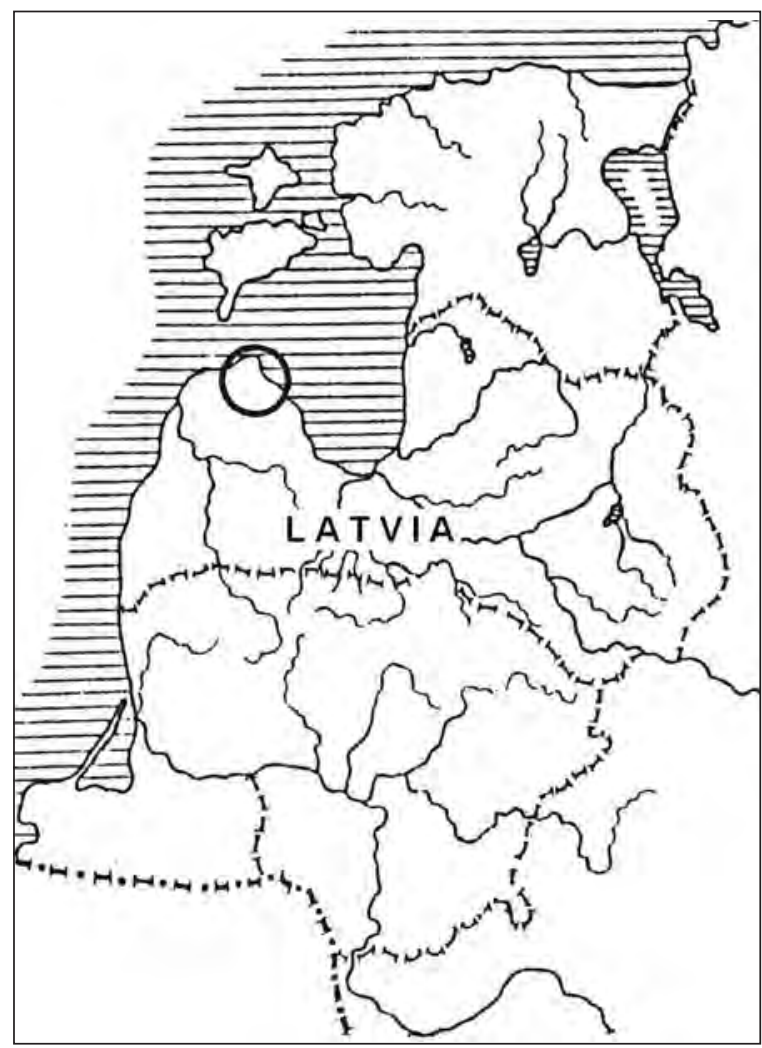

Fig. 1. Location of the Gipka lagoon-paleolake at the North-western part of Latvia.

forehead, projecting shoulders without clearly shaped arms, and a flat base in place of legs. The proportion between the length of the human body and head has not been preserved in the figurine. It has simply not been observed. The back of the figurine is curved, and it resembles a sitting or even squatting human representation. The base in place of legs ensured the figurine stability, and allowed its easy placement on flat surface. Taking one third of the figurine's total length, its head is of a rounded triangular form. Facial details have been modelled using both relief to mark the nose and an incision to mark the eyebrows and eyes. The mouth is not marked. The clay miniature figurine is decorated with rows of fingernailshaped impressions, which on its front and back cross the body transversally. In spite of the primitive modelling of the figurine, it is perfect. The figurine has no pronounced features of gender. It is only $4.4 \mathrm{~cm}$ in length, yet it is rather expressive. The head is turned up towards the roof of heaven. The back of the head and the left shoulder are slightly damaged. 


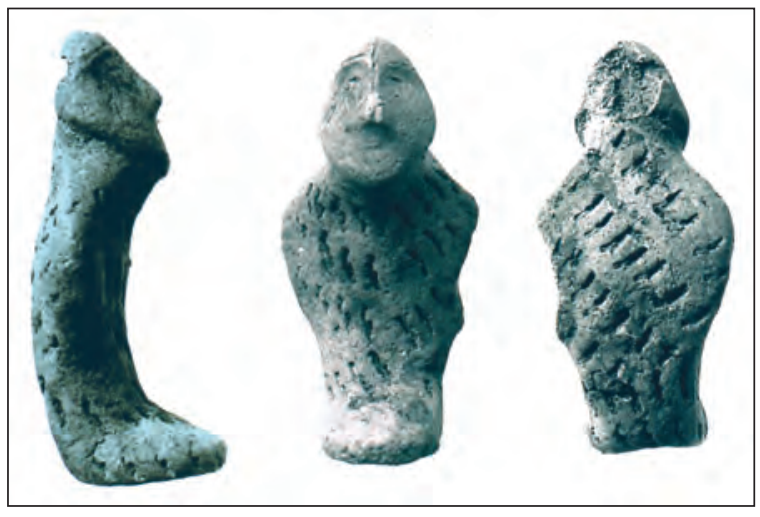

Fig. 3. Anthropomorphic figurine in clay from Pürciems C settlement (after Šturms 1937b).

The makers of the figurines observed an established system of what and how things should be produced in each definite case. Nothing was done by chance. Everything was based on strictly developed rules concerning the making of distinct types of figurine, depending on their specific requirements. One may presume that the figurines of each type had to perform definite functions. In one case they were produced with indications of gender, whereas others they were made without these features. In addition, they could also differ according to the posture, and the posture could indicate either the corresponding individual's attitude towards surrounding nature, living individuals, or could characterise an individual in a concrete situation (unsure, undecided, lost in thought, etc.). Ethno-archaeological data offer plenty of materials about the ambiguity of manufactured dolls or figurines.

Figurines in clay had decorations: ornaments not only served to show clothing and adornments, but also included more profound content. Special signs symbols were incised on clay figurines - on foreheads, temples, chin, shoulders, legs, etc. - that could be interpreted on the basis of both studies of archaeological material and ethno-archaeological abilities.

That the decoration on the figurine from the Pūrciems $C$ site is not accidental can be proven by the breast part of a female figurine found at Iča Late Neolithic settlement (in the wetland of Lake Lubāna) $250 \mathrm{~km}$ from northern Kurzeme (Fig. 4) The sample has rows of fingernail-shaped impressions on its back forming a rhombic motif.

Fingernail-shaped impressions are not only characteristic of miniature objects in clay from the investigated regions. They have also been found on the

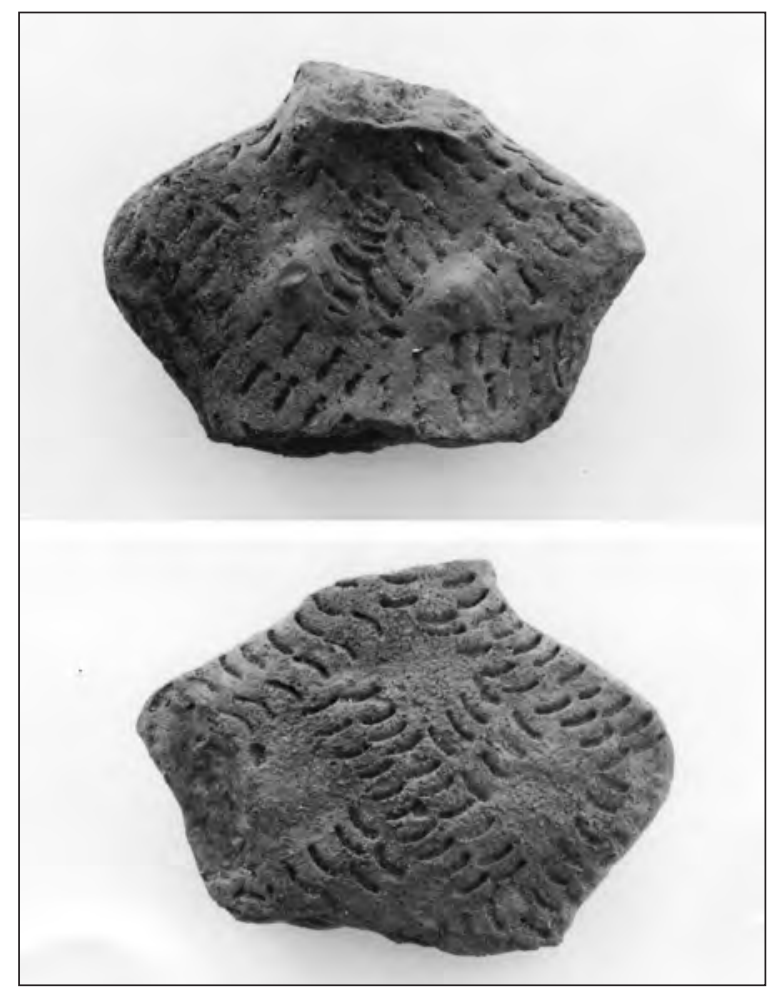

Fig. 4. Upper part of female figurine in clay from Iča Late Neolithic settlement (photo Ilgvars Gradovskis).

surface of pots from excavations at the Gipka A site, where the makers used them in monotonous compositions. Some of the vessels have incidental ochre strewing, evidence of their location in a special zone of the settlement. The pot fragments with the above strewing were also found at the Gipka A site discussed in the present article. They were found in the immediate vicinity of the female breast fragment next to the fireplace (Fig. 12).

The observed regularities of fingernail-shaped decoration were apparently not only connected with the attitude of particular Neolithic humans, women, towards it as a type of decoration, but also as definite information containing an element of ornamentation.

Rhombic motifs, particularly their networks, are characteristic of the Eneolithic ceramics of the Lake Lubāna depression found at Abora and Lagaža sites. The above settlements also offer quartered figurines of contour-rhombi, which have little pits impressed in the centre. These are considered symbols of a farming culture and are called sown field motifs.

\section{Head of the ochre stained figurine}

The head of the anthropomorphic figurine found at Gipka A (Fig. 6) offers new information on the 
above-described type. It might not be viewed as a miniature unit, as here one can deal with a bigger and more significant representation, where the size of the head $(4.14 \mathrm{~cm})$ equals the length of the previously described anthropomorphic figurine.

The figurine from the Gipka A settlement has a rather sharp chin and a straight nose, its form being underlined by an incised vertical line down the whole of the middle of the nose. The figurine has carefully modelled facial features: the nose was formed in relief, while incisions were used to mark the eyes, eyebrows, mouth, nostrils, and a tattoo on the chin. The figurine has broad cheekbones, oblique eyes and narrow forehead. It resembles an individual of Mongoloid origin.

In the area of temples the head has a network of incised rhombi that gives the piece special significance (Fig. 7.1). The face is covered in ochre, and from the forehead down to the chin the colour grows in intensity.

\section{Anthropomorphic clay figurine with a head- dress reminiscent of a scarf (the Gipka type)}

An entirely new type of anthropomorphic clay figurine with a head-dress reminiscent of a scarf was found at Gipka A site (Fig. 8). The modelling of the face, which is $3.6 \mathrm{~cm}$ long, is oval. This means that the representation possibly belongs to an entirely different contingent of people inhabiting the settlement: without broad cheekbones and oblique eyes. The face of the figurine is symmetrical. The nose is made in relief, the closely placed eyes are represen-

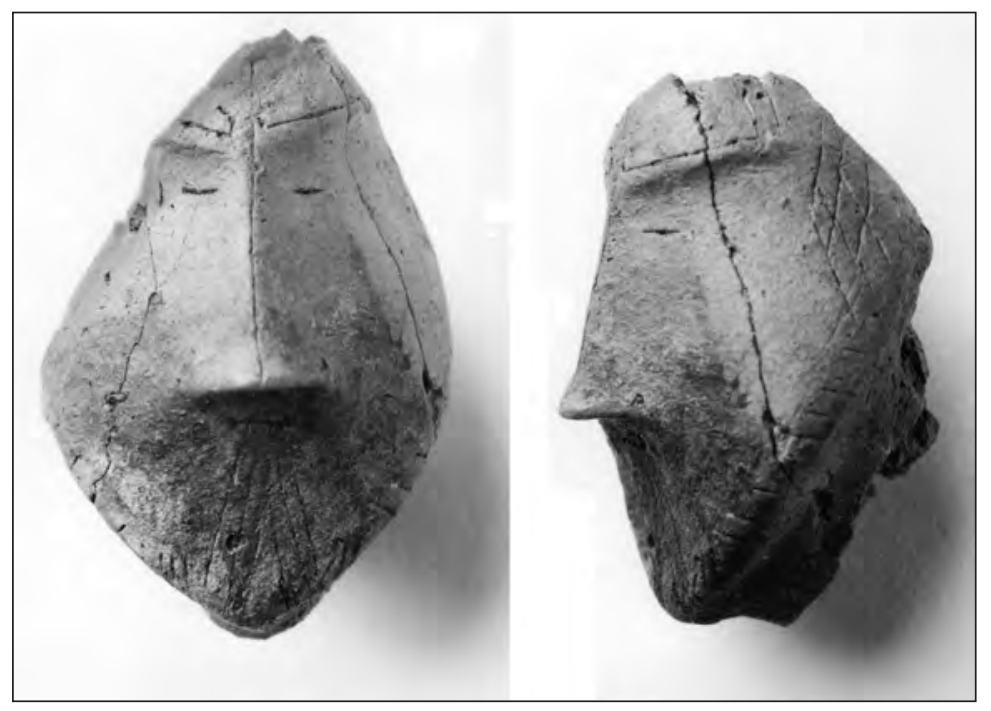

Fig. 6. Head of the anhropomorphic ceramic figurine strewn with ochre from Gipka A settlement (photo: Ilgvars Gradovskis).
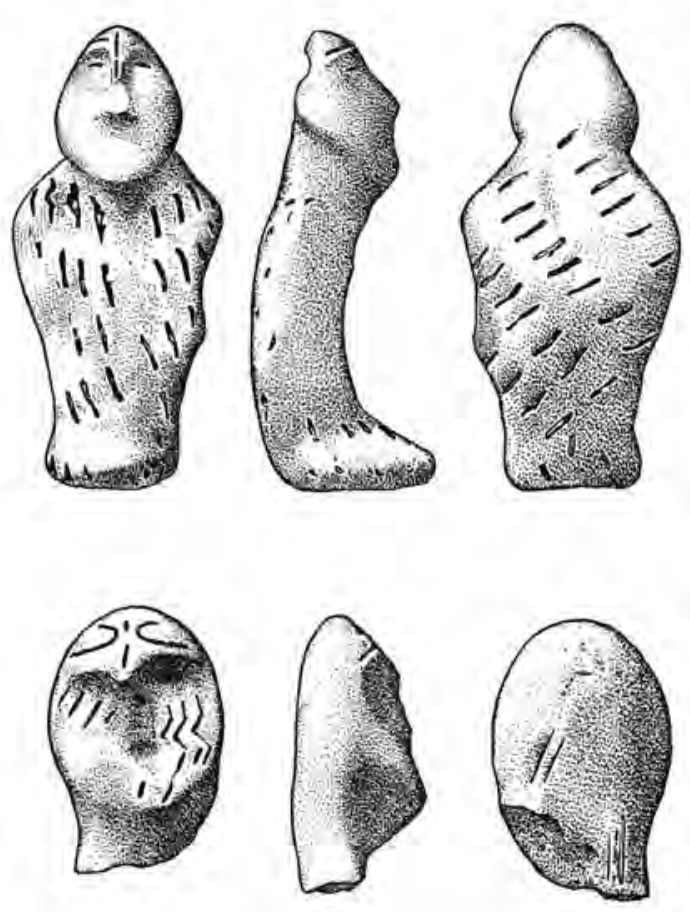

Fig. 5. Anthropomorphic figurines in clay from Pürciems C settlement (drawings of Aiga Ivbule).

ted by small holes while the mouth is engraved. The face has an extraordinary tattoo.

Comprising one third of the length of the face, the rather wide forehead has an incised motif of a walking-stick, with the curve of the upper part placed close to the long line splitting the forehead. In the region of the Eastern Baltics this motif has not been seen before. The remainder of the face and neck are covered by interrelated motifs. The cheeks are decorated with three obliquely incised lines, with smaller opposed incisions at their ends. The walking-stick motif also appears on the chin, where it is included in some other ornamental combination. Four broken vertical incisions under the mouth on the underside of the chin are divided in the following way: the two in the middle join each other, and under the chin on the neck form two rhombic figures incised one into another. The outer incisions, in their turn, form a combination of walking-stick motifs. This is evidence of the joining of different motifs to make a definite ornamental composition, using both geometrical figures (rhomboids) and the original walkingstick motif (Fig. 7.2). 


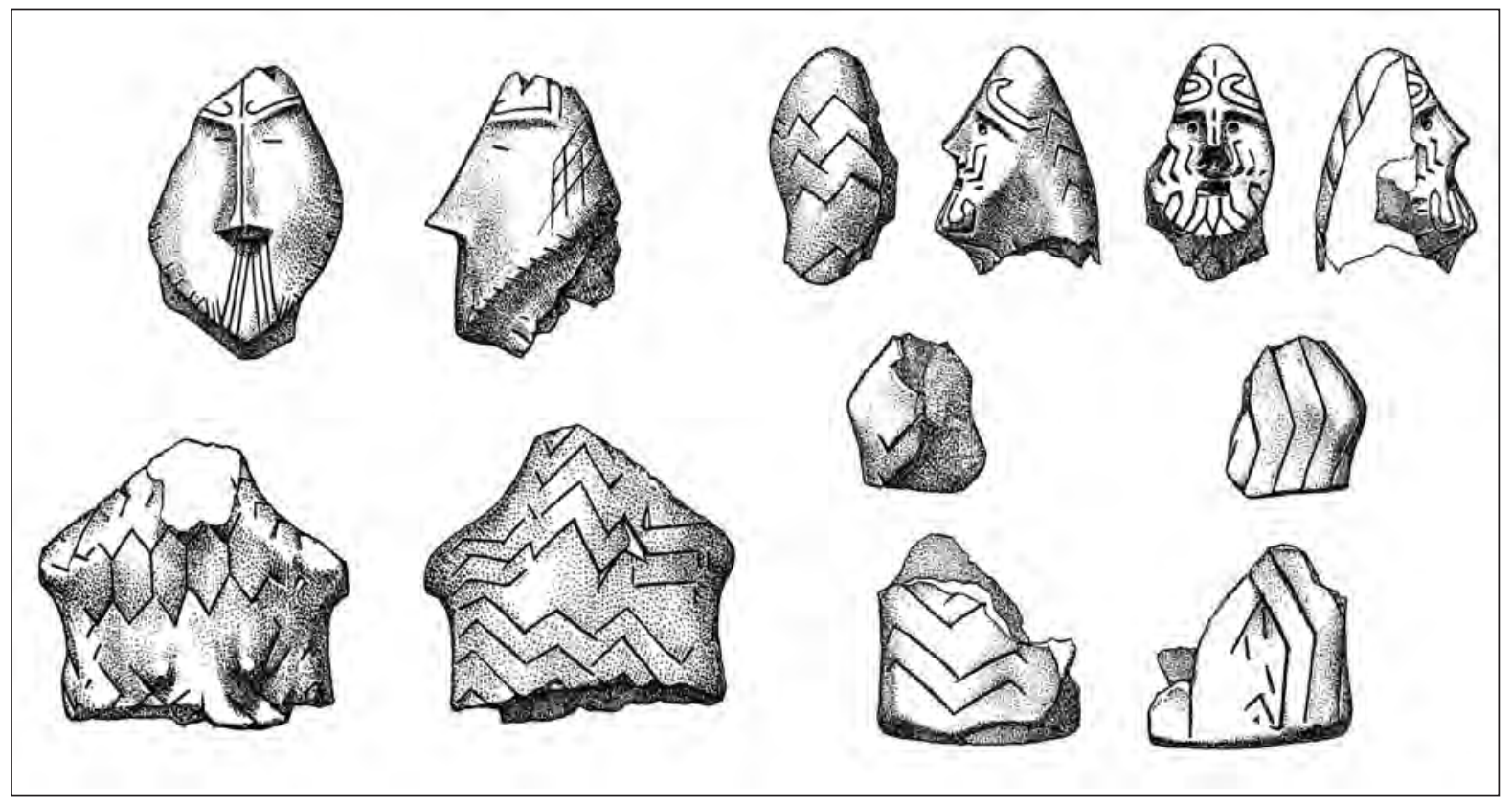

Fig. 7. New discovered small clay plastic art examples from Gipka A settlement (drawings of Aiga Ivbule).

The walking-stick motif, found on the surface of Neolithic anthropomorphic miniatures in southeast Europe, is not only known as a decorative element, but also as a symbolic one, although it has mainly been incised on the breasts, hips, and legs of female figurines (Biehl 1996.157, 159, 160, Fig. 3:19, 5, 6).

The unusual find of the clay figurine with the fascinating Neolithic-Eneolithic farmers' symbols have perplexed researchers of the Eastern Baltic Neolithic, since they have always strictly postulated the idea that farming appeared late in the region. It should therefore be indicated in what conditions the head of the figurine and possible parts of the torso were found at the Gipka A settlement!

The head with farmers' symbols was found in the northern part of the Gipka A site, where archaeologists had discovered a marked off fireplace and the remnants of a threefold fence or walls enclosing a large area (Figs. 9 and 10). It was found under the foot of the western fence, where a funnel-shaped pit, with a diameter of $0.30 \mathrm{~m}$, was specially made before its construction (Fig. 11).

An equal pit, much deeper, however, was also made under the foot of the second fence. A fragment of the figurine's base was found there (Fig. 7.4). skis).

\section{Fragment of the female figurine}

The upper part of the torso of the female figurine from Gipka A is worth special attention (Fig. 12). It was found on its back under the remnants of the fireplace. As shown by its careful placement, the fire was deliberately set after the breaking of the figurine, and its coal and ashes could be gathered from an area over a square kilometre in extent. In this case the figurine was broken in different way: the head and lower part of the trunk were thrown away, and only the female breasts were left there.

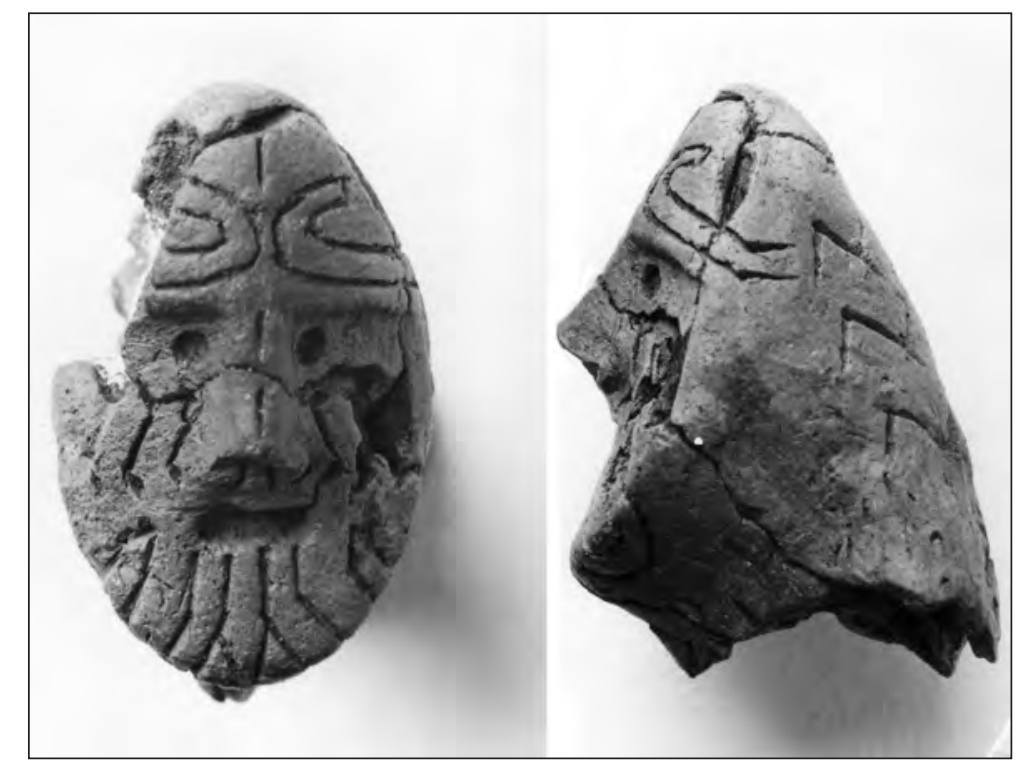

Fig. 8. Head of the anthropomorphic figurine in clay with the headdress reminiscent of scarf from Gipka A (photo: Ilgvars Gradov- 


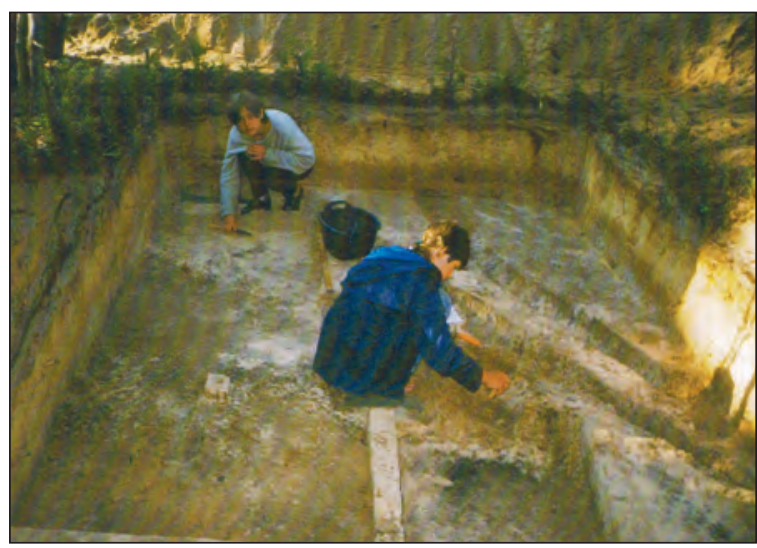

Fig. 9. View to the traces of palisades at Gipka A settlement (photo: Inara Kuniga).

The modelling of the figurine raises interest, too. It has strongly pronounced and projected shoulders, breast projections, and almost polished back. The character of ornamentation, too, gives evidence of a specific role for the figurine in a rite.

Two rows of carefully incised hexagons on the front of the figurine are in sharp contrast with the zigzag ribbons which an experienced hand has made on the back. Moreover, the back growing narrower in its upper part, the zigzags of the upper ribbon are more tightly compressed at its middle. This is a rather successful form of ornamentation.

\section{Anthropomorphic figurines with projections in place of legs}

Among the samples of the miniature figurines in clay of the Litorina blown-out dune settlements found at the newly discovered Gipka A sites, it is also possible to single out a type of figurine different from those having naturalistic modelling with their heads turned upwards and flat bases instead of legs.

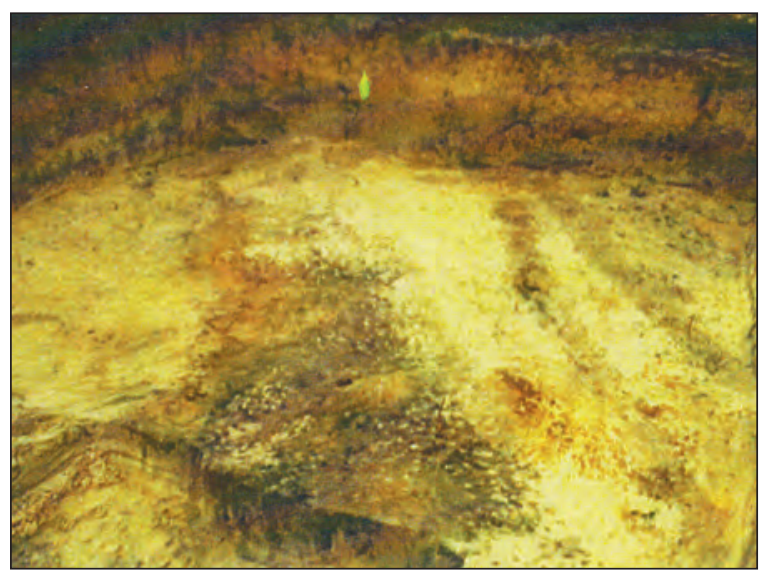

Fig. 10. View to the central fire and traces of palisades. Gipka A settlement (authors' photo).
A separate group is formed of figurines with projections in place of legs. Obtained at Gipka $B$ on the shore-line of a Palaeolithic lake, one of the figurines has flat modelling, without a curved back and features of gender (Fig. 13). The head of the figurine is certainly broken off. The leg projections are not bigger than the shoulder projections of the figurines of type 1 and 2 . The front is decorated with a double row of fine grain-shaped incisions arranged in a crisscross pattern (the length of the fragment does not exceed $3.6 \mathrm{~cm}$ ).

The figurine from the Gipka A site with strongly pronounced projections in place of legs is undoubtedly an entirely different type of figurine (Fig. 14). Only the lower part has survived. It was made independently from other part, to allow later seating into it the rest of the trunk and head. Both figurines could easily be stuck in the dune sand. They were, certainly, not meant for putting on a hard surface.

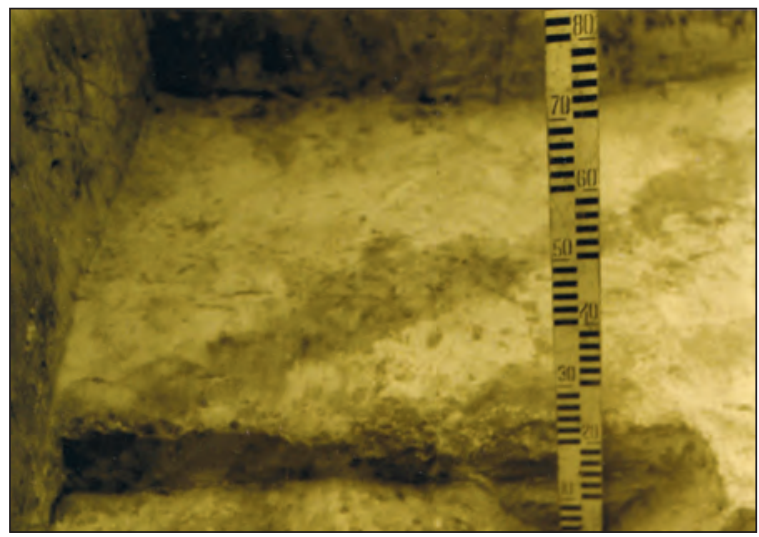

Fig. 11. View to the small pit (with finds of two broken ceramic figurines) under the foundation of palisade. Gipka A settlement (authors' photo).

\section{Miniature bead-shaped representation of a head}

A miniature bead-shaped anthropomorphic representation of a head containing a hollow inside was found at the Gipka B site (Fig. 15). It could have been worn around the neck as a bead. A relief is used to model facial details that mark a flat and rather broad nose. The line of the mouth is incised. The upper part of the head is also separated by an incised line forming a hat-like head-dress. Like nearly all the others, this sample of miniature ceramic anthropomorphic figurines is the only known piece from the Eastern Baltics, and the acquisition indicates the large unexhausted opportunities for research into Neolithic such material in the dunes of northern Kurzeme. 


\section{OCHRE SYMBOLS IN THE DUNES OF NORTHERN KURZEME}

Archaeological excavations at the Gipka A site show that the inhabitants of the settlement used ochre in great quantities. The first evidence of this was a clay pot, flattened by the weight of dune sand, which contained a great amount of ochre powder. It was located in the eastern part of the fixed central fireplace (Fig. 10). Alongside a well-pronounced coal layer in the fireplace, here and there above it and north-west behind it, ochre strewing was also found. All the above is evidence of lively activity by more than one person connected fire and a procedure of some definite character.

Recovered in the northern part of area $\mathrm{C}$, the central fire place is in a layer of white sand. In the area of the recovered settlement, the layer is characterized by the presence of tiny circular coal spots. Burning was, apparently, carried out frequently, and sea winds carried the ash in all directions. Alongside the coal marks, very small ochre spots were also found here and there, suggesting human activity.

The inhabitants of the Gipka lagoon obtained ochre in low and wet areas and burnt it to obtain the colour of blood. From there they took it to the dunes of the Litorina Sea to use it for their needs.

The face of the anthropomorphic figurine from Gipka A was entirely stained with ochre (Fig. 6) the chin most markedly. In such a way, the ochre not only made the head of the figurine more visible, but also reanimated it.

Red is one of the three colours (with white and black) that is included among the universal colour classification systems of archaic societies. According to Victor Turner suggested that the three colours are not only subject to different perceptions of the different ranges of these colours, but are rather concise denotations of rich psycho-physiological experiences affecting both reasoning and the sense organs connected with the primary group relations (Turner 1966.80).

The Neolithic society of Northern Kurzeme attributes several meanings to ochre. Similarly, the red colour of the clay at the Zvejnieki site on the coast of Lake Burtnieku (a mask of red clay covers the face of burial 263); in the north of Latvia the colour of ochre is the symbol of blood. If the face of a well-to-do man was not covered with a mask of red clay, a mask of

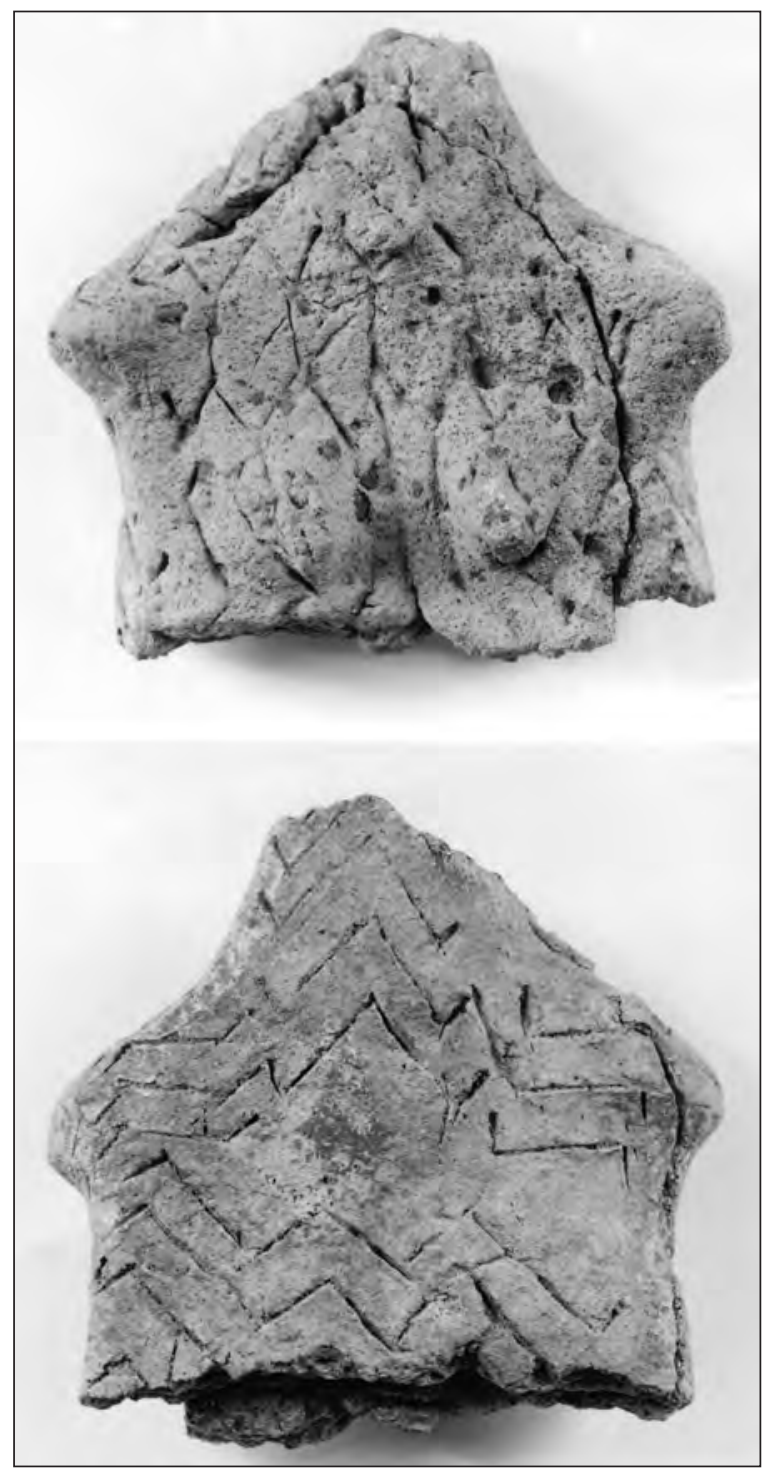

Fig. 12. Upper part of the trunk of female ceramic figurine from Gipka A settlememt (photos: Ilgvars Gradovskis).

bluish clay could also be used. However, the dead individual with a mask of the bluish clay was reanimated with the help of ochre powder (burial 275) ( $\mathrm{Za}$ gorskis 2004.45).

As shown by ethno-archaeological data on the inhabitants of the Lower Congo, the painting of a corpse and its shroud in red has been a tradition practise until quite recently (Jacobson-Widding 1979.167180).

Red has a of meanings. It could be useful to note here the interpretation of red given by the Ndembi of Zambia as recorded by Victor Turner, who spent many years in Zambia, mastered the language of the local people and is one of the founders of symbolic anthropology. The Ndembi associate red things with 
blood and clay; however, their explanation is much wider (Turner 1983.82-83):

- blood of animals;

- blood of mother;

- blood of all women;

- blood of a murder;

- blood of sorcery (it should be associated with necromancy); moreover, it can be both good and evil;

- red things have power; blood is power, humans, animals, insects or birds, therefore, need blood. Wooden figurines are bloodless, so they cannot breathe, speak, laugh and communicate; they are simply pieces of wood. Only when sorcerers manipulate them, give them blood, can the figurines function and kill people.

Of the anthropomorphic clay figurines from the Gipka A site, only one had a face stained with ochre. Hence, only one of the recovered figurines had been active at the time, and was thus symbolising a definite person. However, like all the other figurines at Gipka A, it was broken. While killing others, the figurine itself had also been killed and destroyed.

\section{RITE IN THE DUNES OF NORTHERN KURZEME}

The figurines found at Gipka A were not located on a bare field. Archaeologists have facts indicating that they were used in special cases, and, probably, together with burning of very large or smaller fires. The settlement had three different floor levels. As indicated above, their figurines were of different types, or, to put it in other words, they differed in style. This means that the different figurines could represent different groupings of people, since the stylistic solidarity of figurines underlines the solidarity of corresponding groupings who came to visit the dunes. Some of them manufactured figurines with broad cheekbones and low foreheads, others with an oval face. Regardless of the complexity of their interpretation, all figurines are interconnected through their occurrences in the settlement.

Hence, at Gipka A settlement there was a special place where a definite action took place. It could have been the cycle of a certain rite accompanied by larger or smaller fires.

In any stage of human development, fire and fire places are associated with light, warmth, cooking in this case - defence, hunting, preparing the first fields for farming, sowing, etc. However, in a certain

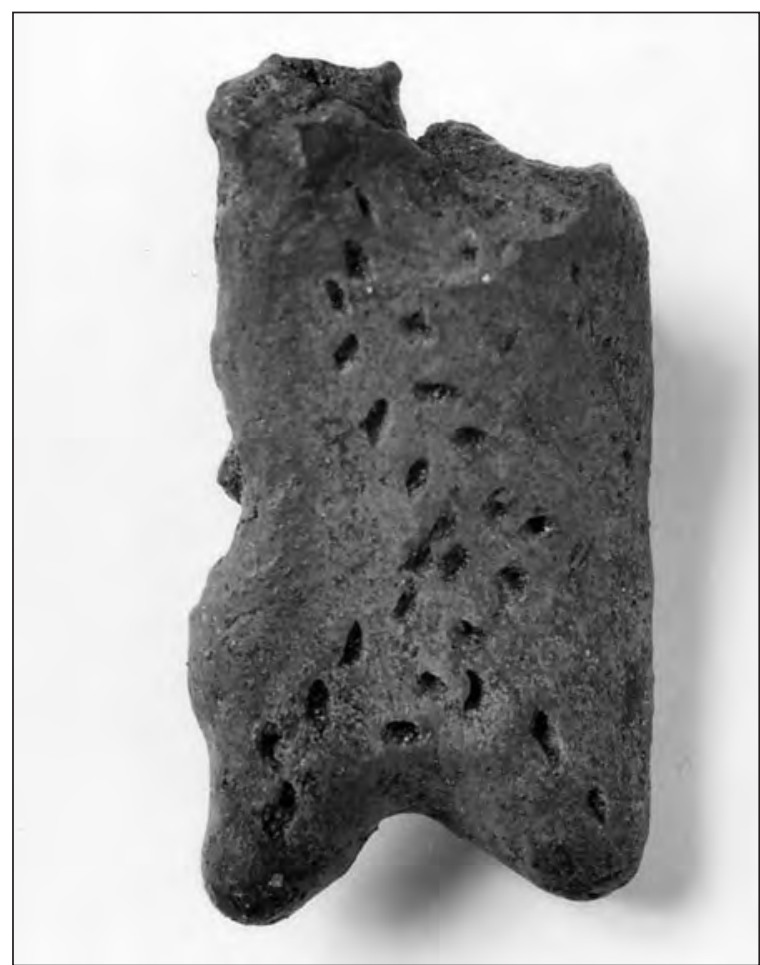

Fig. 13. Flat anthropomorphic figurine from Gipka B settlement (photo: Ilgvars Gradovskis).

cycle of human development, fire is also associated with other functions, fire is used at special events related to the spiritual world. Reanimation-ochering of clay figurines and their breaking, and putting of unochered, that is, dead, figurines into specially made pits is evidence of special rites practised in the dunes of Neolithic northern Kurzeme.

According to ethno-archaeological data collected among the Aborigines, a rite is an arrangement of stereotyped actions including a combination of specially developed gestures, words and applied objects (in this case, clay figurines). They serve a definite function, and the performance is usually in specially prepared environments (in this case, specially built dwellings on the shore of the Litorina Sea). The action is undertaken to influence supernatural forces and beings for the benefit of the actors. Rites are performed in connection with seasonal change and special events of the season, as well as with dramatic moments in the lives of individuals or the whole community. Rites were used to assuage or drive away supernatural forces and beings which negatively affected the community. Through rites Neolithic society sought to become free of evil and ill-disposed forces and improve the standards of their social life. The principal purpose of a rite could also be divination. Likewise, the widespread procedure of divination (by special sorcerers) rites were always perfor- 
med by one and the same people - those who had earned respect and who stood out from other members of the community through their wisdom, and physical and spiritual strength.

The smallest and simultaneously the most significant unit of the rite is a symbol that maintains the rite's specificity through its entire procedure. In the context of a rite, a symbol is considered a semantic element, since it is related to signs and symbols and things with which the symbols are associated (Turner 1983.33). Symbols may have very different meanings, even being of entirely opposite characters.

In the research practice of the Eastern Baltic Neolithic this is the first case when it is possible to see the spatial context of religious or cultic practise. By this the following five interrelated zones are understood: place, imagery, devices and support, participants and practices/actions (Bertemes, Biehl 2001. 17-20). And this can also be referred to the Middle Neolithic Gipka settlements. A site where rites were performed was found there, and it was connected with the burning of a large fire and the manufacture of clay figurines which had been stained with ochre. Ochre was used there in great quantities (the find of a clay pot filled with ochre powder), and was used to reanimate figurines and subsequently break them.

Under the palisades that surrounded the settlement, special pits were dug, and by filling them the fence was erected. The undertaking involved more than one participant, yet one particular person had led it. The cycle of the rite was connected with its smallest unit - a symbol, that in present case could have been the walking-stick motif depicted on the forehead of the clay figurine.

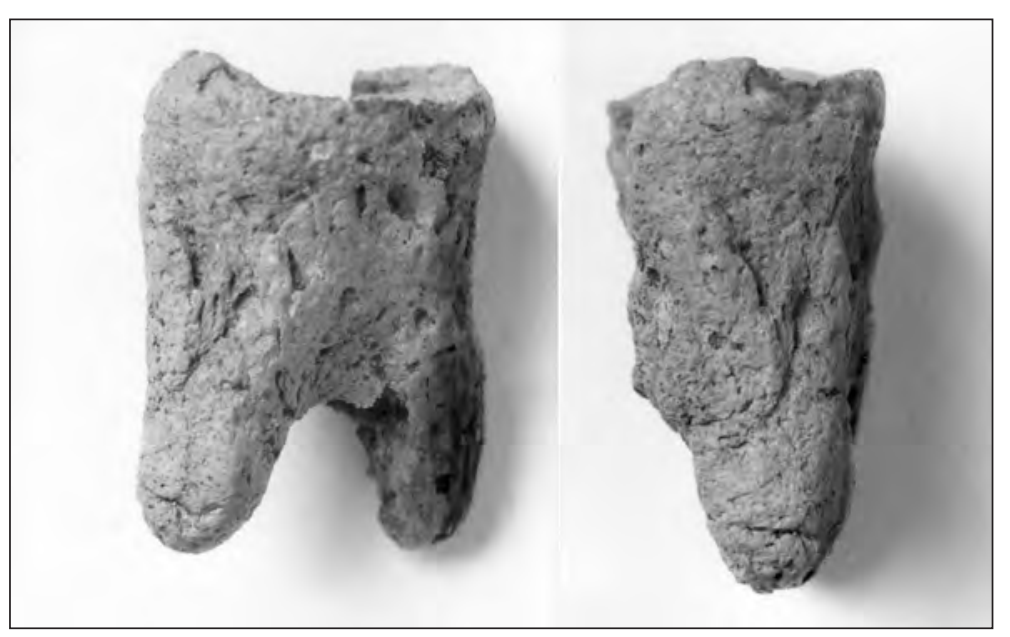

Fig. 14. The lower part of broken anthropomorphic figurine from Gipka A settlement (photo: Ilgvars Gradovskis).
A flint sickle-shaped knife broken precisely in half which was found in the immediate vicinity of the fire at Pürciems F site suggests a symbol of a culture familiar with farming (Loze 1997.193, Fig. 7.13). Likewise at Gipka A and Pürciems C, the upper settlement has broken clay figurines, and these sites were inhabited by people of the same Neolithic culture. Further evidence for this is the presence of Cerelia pollen in the occupational layer of Gipka B settlement, in the immediate vicinity of the lagoon, later a lake (Jakubovska 2005).

It is true that Gipka A and other newly discovered sites, altogether 4 units, are special types of palisade enclosures which were temporarily occupied by Middle Neolithic people. In our case we have multiple palisades. Three of them were in parallel $(10 \mathrm{~m}$ inside the excavation area) but the fourth, very small one, which was the earliest, was different. According to data from palisade enclosures in Denmark, sites as those at Gipka A are religious meeting places (Nielsen 2004.20).

\section{SYMBOLS ON THE FACES OF CLAY FIGURINES FROM NORTHERN KURZEME}

Clay figurines from the Gịka-Pūrciems settlements are not simple anthropomorphic representations. They have had far greater significance than we have been able to perceive. Their special significance is emphasised by their ornamentation, and the symbols depicted on their forehead, face, back or breasts.

The clay figurines from the Gipka and Pūrciems C sites have the following decorations on various parts of the head and body:

- Rhombic network (without contour);

- Walking-stick motif (double line);

- Vertical line with opposed tiny incisions at each end;

- Broken horizontal line with a tiny inverse incision;

- Zigzag ribbon;

- Hexagon.

All the above types of decorations are geometrical ornaments, except the walking-stick motif. This fascinating sign - a walking-stick shaped line or double line is characteristic of female figurines from farming cultures in south east Europe, and its re- 
presentation on the face of the figurine found at Gipka A site is possibly an agricultural symbol (Fig. 8). From where and how did appear here? Having carefully examined the miniature anthropomorphic figurine from Pūrciems $\mathrm{C}$ with the broad cheekbones and low forehead, one may conclude that instead of eyebrows there is a weakly pronounced walkingstick shaped line (Fig. 3). A weakly incised walkingstick line could also be seen on the oval face of the figurine (Fig. 5.2). Hence we may conclude that the motif had initially been hardly visible, until a later period and different conditions, when it appeared in all its beauty, and in a well considered and complete composition with other motifs.

The face of the clay figurine from Gipka A site may contain information which might remain unknown unless we seek some parallels to the walking-stick motif elsewhere. There have been indications of it before. Attention was attracted by a walking stick motif found in southeast Europe, where it could be seen on pieces of female figurines from early farming cultures (Biehl 1996.157, Fig. 3.4, 19). As shown by special studies, here they appear on the breasts, hips, and legs of the figurines. According to the opinion of specialists, the above motif is a symbol that forms a far-reaching communication system. The same can be said about many other motifs of early farming cultures.

Thus the decoding of the above symbol connects us with the early agricultural cultures. And in this case the fact that the Neolithic coastal settlements of Northern Kurzeme belong to the Culture of Pit Ceramics even intensifies the significance of the symbol among the inhabitants of the region.

The Culture of Pit Ceramics is characterised by a complex economy, and in the settlements of the

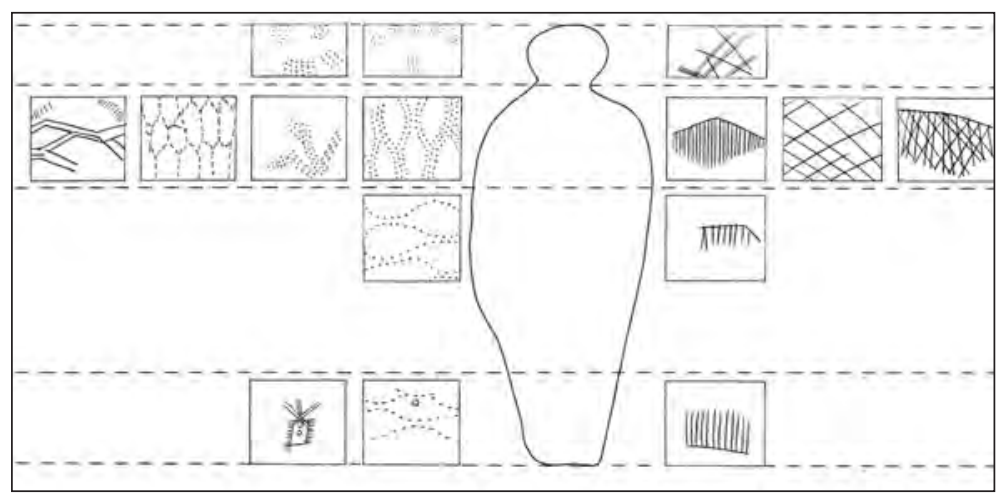

Fig. 16. Ornament and main design motifs of ceramic anthropomorphic figurines from Jetbolle II. settlement, Jomala island. (After Cederhvarf 1912, Nunez 1986; drawings of Aiga Ivbule).

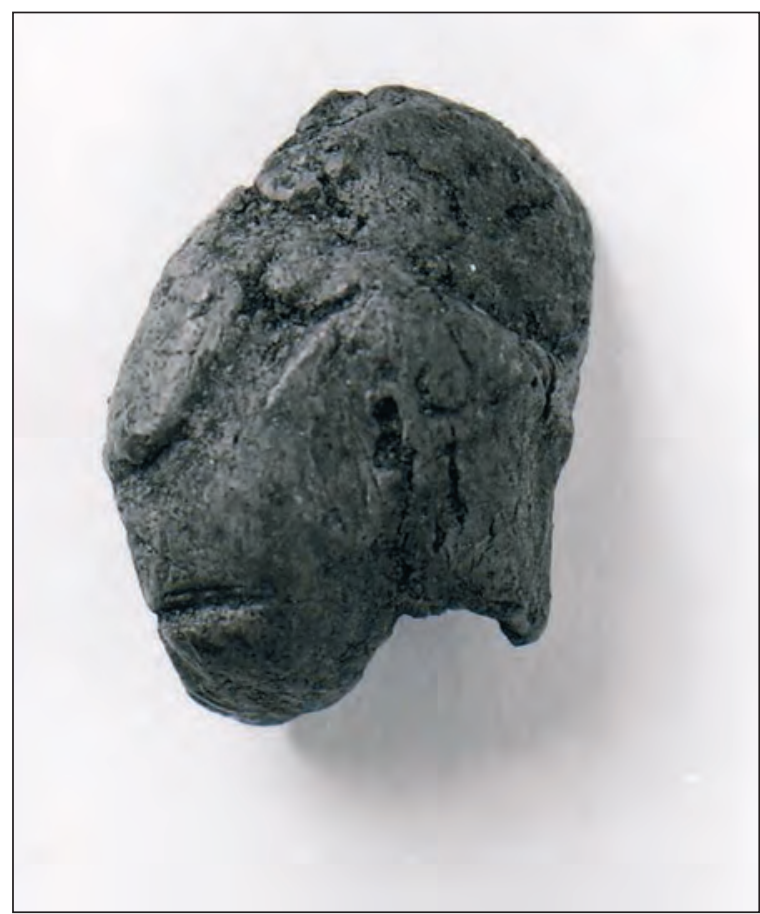

Fig. 15. Bead-shaped anthropomorphic head figurine. Gipka B settlement.

same culture in Scandinavia, the model may differ. At the Åby settlement in Gotland, there is a site typical of the culture located not that far from Northern Kurzeme, where the bulk of material consists of fish and seal bones. However, the bones of cattle, pigs and dogs were also found there (Malmer 2003.129). In Scandinavia, the economy of the Culture of Pit Ceramics is interpreted as combining hunting and farming.

The anthropomorphic clay figurines of Northern Kurzeme comprise a portion of anthropomorphic samples of miniature figurines made by the Middle Neolithic inhabitants from the coastal zone of the Baltic basin. It is therefore useful to compare them with the figurines obtained from the Aland group. The original symbols of the figurines from Northern Kurzeme, including that of the walkingstick motif, have no parallels with the symbols on the anthropomorphic figurines from the Ålands.

However, the incised net-shape and hexagon motif found on the head of the ochre-stained figurine and the breast of the female figurine from Gipka A (Figs. 6 and 12) is common to both groups of figurines (Fig. 16). This shows that, regardless of the in- 
dividual system of symbols characteristic of the groups of inhabiting Northern Kurzeme and the Ålands, some symbols are similar. As proven by ethno-archaeological materials from Africa, simple geometrical symbols may include conscious references. They may designate living creatures, parts of the human body or inanimate objects, features of the landscape, etc. It has been emphasised that in spite of minor differences in simple symbols, they may relate to substantially different meanings (Hodder 1982.171).
By shading in the incised conventional geometric figurines, their meaning is changed. They become symbols designating other things or living beings. Like the anthropomorphic clay figurines from the Alland Isles, the pieces from Northern Kurzeme open unique possibilities for research into systems of archaic symbols, traces of which can be sought in the symbols of Africa and other continents.

\section{REFERENCES}

ÄYRÄPÄÄ A. 1942. Kampakeramisen kultturin savikuviot. Suomen Museo XLVIII: 82-123.

BERTEMES F., BIEHL P. F. 2001.The Archaeology of Cult and Religion. An introduction. In P. F. Biehl and F. Bertemes with H. Miller (eds.), The Archaeology of Cult and Religion: 11-20.

BIEHL P. H. 1996. Symbolic communication systems: symbols on anthropomorphic figurines of the Neolithic and Chalcolithic from South-Eastern Europe. Yournal of European Archaeology 4: 153- 176.

CEDERHVARF B. 1912. Neolitiska lerfigurer från Åland (Ett förelöpande meddelande). Finska fornminnesföreningens TIDSKRIFT XXV: 307- 323.

EBERHARDS G. 2000. Litorina Sea coastal formations and the origins of Stone age habitation of the shore of the gulf of Riga in Northern Kurzeme: Geological background (in Latvian with English summary). $A r$ heologija un Etnogrāfija. XX. Rìga: 211-222.

JACOBSON-WIDDING A.1979. Red-White-Black as a Mode of Thought. Almmqvist and Wiksell. Uppsala.

JAKUBOVSKA I. 2005. Anthropogenic activities in Middle Neolithic settlements of Gipka lagoon-paleolake (North-western part of Riga Gulf). (in print).

HODDER I. 1982. Symbols in Action. Cambridge University Press Cambridge.

LOZE I. 1997. The Neolithic Dune dwellings in Dundagas Pūrciems (Latvia). In Danuta Król (ed.), The Built Environment of Coast Areas during the Stone Age: 186- 196.
2002. Some aspects of Neolithic ritual at the dune settlements of Northern Kurzeme (In Latvian with English summary). Acta Historica Vindaviensia II. Riga: 52- 61.

2004. Northern Kurzeme Neolithic Miniature Plastic Art in Clay. In V. Poikalainen and E. Ernits (eds.), Aurinkopeura 2. Eesti Muinastaideselts. Suomen muinaistaideseura: 67-83.

MALMER M. P. 2002. The Neolithic of South Sweden. TRB, GRK, and STR. The Royal Swedish Academy of Letters and Antiqiuties: 294 pp.

NIELSEN P. 0. 2004. Causewayed camps, palisade enclosures and central settlements of the Middle Neolithic in Denmark. Yournal of Nordic Archaeological Science 14:19- 33.

NUNEZ M. G. 1986. Clay figurines from the Åland Islands and Mainland Finland. Fennoscandia Archaeologica III: 17- 34 .

ŠTURMS E. 1937a. Neolita apmetne Dundagas Pūrciemā (Die neolithische Siedlung bei Pūrciems, Gem. Dundaga). Senatne un Māksla I (Antiquity and Art I): $46-54$.

1937b. Senākie cilvēka tēli Latvijā (Ancient Human Representation in Latvia). Senatne un Māksla. IV: 83- 91 .

TURNER R. V. W. 1983. Symbol and Ritual (Selected papers in Russian). Editoras Board of East literature. Moscow.

ZAGORSKIS F. 2004. Zvejnieki (Northern Latvia) Stone Age Cemetery. BAR International Series 1292. 